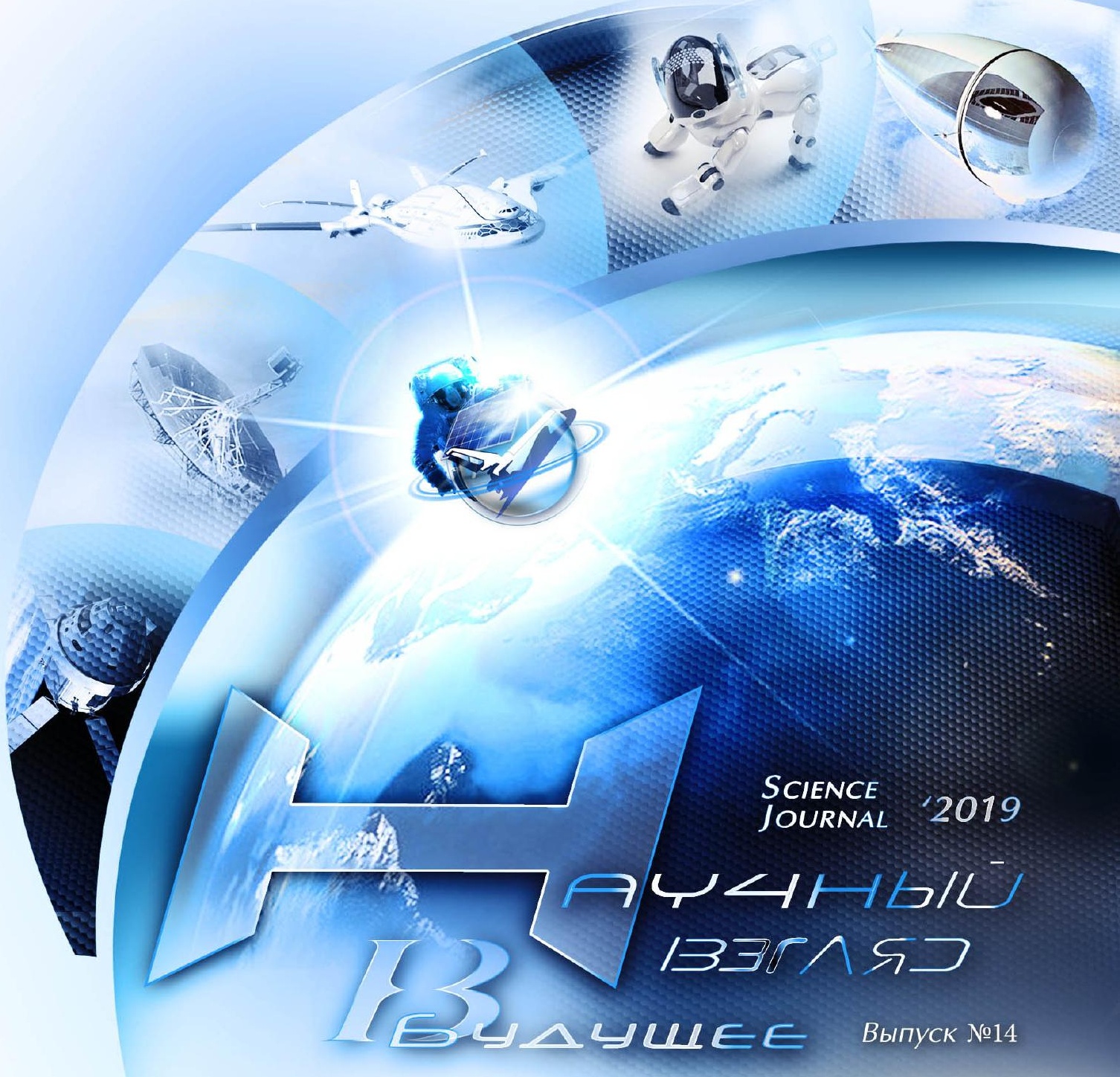




\section{Институт морехозяйства и предпринимательства}

При научной поддержке:

Экономическая академия им.Д.А.Ценова (Болгария)

Московский государственный университет путей сообщения (МИИТ)

Украинская государственная академия железнодорожного транспорта

Научно-исследовательский проектно-конструкторский институт морского флота

Луганский государственный медицинский университет

Харьковская медицинская академия последипломного образования

Бельцкий Государственный Университет «Алеку Руссо»

Институт водных проблем и мелиорации Национальной академии аграрных наук

Одесский научно-исследовательский институт связи

\section{Международное периодическое научное издание}

International periodic scientific journal

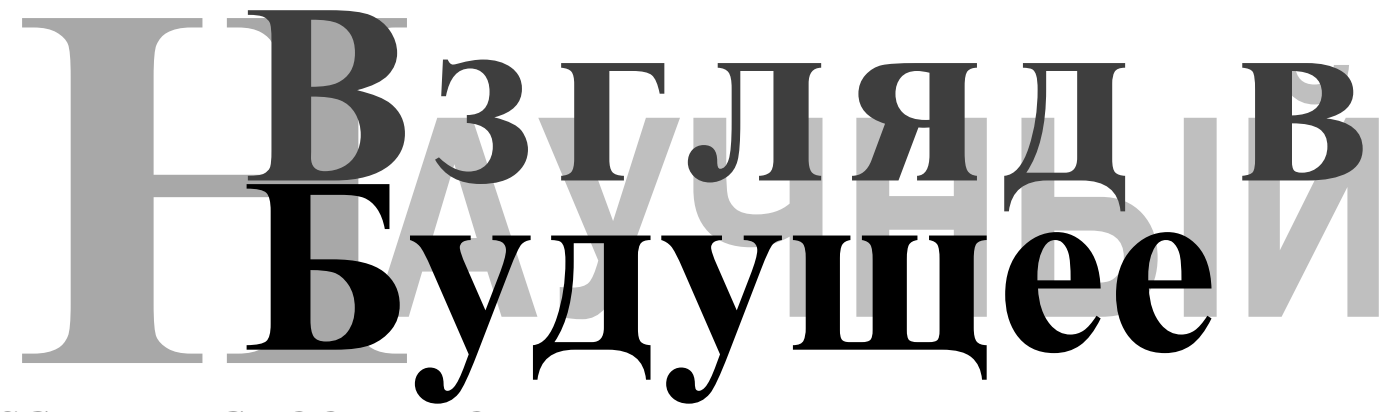

\section{SCIENTIFIC LOOK INTO THE FUTURE}

НАУКОВИЙ ПОГЛЯД У МАЙБУТНЕ

\section{Выпуск №14, июнь 2019}

Issue №14, June 2019

Toм 1

Part 1 
УДК 08

ББК 94

H 347

\section{Главный редактор:}

Шибаев Александр Григорьевич, доктор технических наук, профессор, Академик Головний редактор:

Шибаєв Олександр Григорович, доктор технічних наук, професор, Академік

Chief Editor:

Shibaev Alexander Grigoryevich, Doctor of Technical Sciences, Professor, Academician

\section{Заместитель Главного редактора:}

Яценко Александр Владимирович, кандидат технических наук, профессор, Ректор ИМП Заступник головного редактора:

Яценко Олександр Володимирович, кандидат технічних наук, професор, Ректор IМП Deputy Chief Editor:

Yatsenko Alexander Vladimirovich, Candidate of Technical Sciences, Professor, Rector of ISE

\section{Редакционный Совет:}

Более 160 докторов наук. Полный список представлен на страницах 3-5. Редакційна Рада:

Понад 160 докторів наук. Повний список представлений на сторінках 3-5.

Editorial Board:

More than 160 doctors of sciences. The full list is available on pages 3-5.

Н 347 Научный взгляд в будущее. - Выпуск 14. Том 1. - Одесса: КУПРИЕНКО СВ, 2019 - 122 с.

Журнал предназначается для научных работников, аспирантов, студентов старших курсов, преподавателей, предпринимателей.

The journal is intended for researchers, graduate students, senior students, teachers and entrepreneurs. Published quarterly. 


\section{Редакционный Совет}

Бухарина Ирина Јеонидовна, доктор биологических наук, профессор, Рос Россия

Гриценко Светлана Анатольевна, доктор биологических наук, доцент, Россия Каленик Татьяна Кузьминична, доктор биологических наук, профессор, Россия

Князева Ольга Александровна, доктор биологических наук, доцент, Россия Кухар Елена Владимировна, доктор биологических наук, доцент, Казахста Моисейкина Людмила Гучаевна, доктор биологических наук, профессор, Россия

ередьева Елена Эдуардовна, доктор биологических наук, доцент, Россия Россия

Стародубцев Владимир Михайлович, доктор биологических наук, профессор,

Украина

Тестов Борис Викторович, доктор биологических наук, профессор, Россия Тунгушбаева Зина Байбагусовна, доктор биологических наук, , Казахстан Фатеева Надежда Михайловна, доктор биологических наук, профессор, Россия

Ахмадиев Габдулахат Маликович, доктор ветеринарных наук, профессор,

Шевченко Лариса Васильевна, доктор ветеринарных наук, профессор,

Анимица Евгений Георгиевич, доктор географических наук, профессор,

Россия

Сухова Мария Геннадьевна, доктор географических наук, доцент, Россия Иржи Хлахула, доктор геолого-минералогических наук, профессор, Чехия Федоришин Дмитро Дмитрович, доктор геолого-минералогических наук,

покебаева Гульжаухар Какеновна, доктор исторических наук, профессор,

Казахстан

Отепова Гульфира Елубаевна, доктор исторических наук, профессор,

Тригуб Петр Никитович, доктор исторических наук, профессор, Украина Визир Вадим Алибор , доктор исторических наук, доцент, Сербия Украина Федянина Людмила Николаевна, доктор медицинских наук, профессор,

Россия

Орлов Николай Михайлович, доктор наук государственного управления,

доцент, Украина

Величко Степан Петрович, доктор педагогических наук, профессор, Украина Гавриленко Наталия Николаевна, доктор педагогических наук, доцент,

Гилев Геннадий Андреевич, доктор педагогических наук, профессор, Россия орофеев Андрей Викторович, доктор пед гогигески

Россия

Мишенина Татьяна Михайловна, доктор педагогических наук, профессор,

Украина

Николаева Алла Дмитриевна, доктор педагогических наук, профессор,

Россия
Расррыгина Алла Николаевна, доктор педагогических наук, профессор,

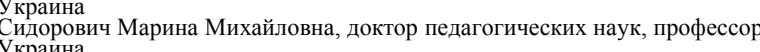

Смирнов Евгений Иванович, доктор педагогических наук, профессор, Россия Федотова Галина Александровна, доктор педагогических наук, профессор, Редсия

Ходакова Нина Павловна, доктор педагогических наук, доцент, Россия

Чигиринская Наталья Вячеславовна, доктор педагогических наук, профессор, Россия

Чурекова Татьяна Михайловна, доктор педагогических наук, профессор,

Латыгина Наталья Анатольевна, доктор политологических наук, профессор,

Украина

Сирота Наум Михайлович, доктор политологических наук, профессор,

Хребина Светлана Владимировна, доктор психологических наук, профессор,

Россия

Вожегова Раиса Анатольевна, доктор сельскохозяйственных наук, профессор,

Украина

Денисов Сергей Александрович, доктор сельскохозяйственных наук,

профессор, Россия

Жовтоног Ольга Йгоревна, доктор сельскохозяйственных наук, , Украина

Костенко Василий Иванович, доктор сельскохозяйственных наук, профессор,

Украина

作

профессор, Россия

Владимирович, доктор сельскохозяйственных наук,

профессор, Украина

профессор, Украина

Ребезов Максим Борисович, доктор сельскохозяйственных наук, профессор, Россия

Тарарико Юрий Александрович, доктор сельскохозяйственных наук, профессор, Украина Стегний Василий Николаевич, доктор социологических наук, профессор, Россия Василий Николаевич, доктор социологических наук, профессор, Тарасенко Лариса Викторовна, доктор социологических наук, профессор Аверченков Владимир Иванович, доктор технических наук, профессор, Антонов Валерий Николаевич, доктор технических наук, профессор, Украина Быков Юрий Александрович, доктор технических наук, профессор, Россия Гончарук Сергей Миронович, доктор технических наук, профессор, Россия Гахаров Олег Владимирович, доктор технических наук, профессор, Россия Калайда Владимир Тимофеевич, доктор технических наук, профессор, Россия Кириллова Елена Викторовна, доктор технических наук, доцент, Украина Коваленко Петр Иванович, доктор технических наук, профессор, Украина Ковей Богдан Владимирович, доктор технических наук, профессор, Украина Косенко Надежда Федоровна, доктор технических наук, доцент, Россия Круглов Валерий Михайлович, доктор технических наук, профессор, Россия Кудерин Марат Крыкбаевич, доктор технических наук, профессор, Казахстан Лебедев Анатолий Тимофеевич, доктор технических наук, профессор, Россия Ломотько Денис Викторович, доктор технических наук, профессор, Украина Макарова Ирина Викторовна, доктор технических наук, профессор, Россия Павленко Анатолий Михайлович, доктор технических наук, профессор,
Украина

Парунакян Ваагн Эмильевич, доктор технических наук, профессор, Украина Пачурин Герман Васильевич, доктор технических наук, профессор, Россия Першин Владимир Федорович, доктор технических наук, профессор, Россия Пиганов Михаил Николаевич, доктор технических наук, профессор, Россия
Поляков Андрей Павлович, доктор технических наук, профессор, Украина
Попов Виктор Сергеевич, доктор технических наук, профессор, Россия Рокочинский Анатолий Николаевич, доктор технических наук, профессор, Украина

Ромащенко Михаил Иванович, доктор технических наук, профессор, Украина Семенцов Георгий Никифорович, доктор технических наук, профессор, Украина

Сухенко Юрий Григорьевич, доктор технических наук, профессор, Украина Устенко Сергей Анатольевич, доктор технических наук, доцент, Украина Хабибуллин Рифат Габдулхакович, доктор технических наук, профессор, Червоный Иван Федорович, доктор технических наук, профессор, Украина Шайко-Шайковский Александр Геннадьевич, доктор технических наук, профессор, Украина

щербань Игорь Васильевич, доктор технических наук, доцент, Россия Бушуева Инна Владимировна, доктор фармацевтических наук, профессор, Украина
Волох Дмитрий Степанович, доктор фармацевтических наук, профессор, Украина

Георгиевский Геннадий Викторович, доктор фармацевтических наук, старший научный сотрудник, Украина

Гудзенко Александр Павлович, доктор фармацевтических наук, профессор,

Ткраина

Александр Иванович, доктор фармацевтических наук, профессор,

Украина

Шаповалов Валерий Владимирович, доктор фармацевтических наук,

профессор, Украина

Шаповалова Виктория Алексеевна, доктор фармацевтических наук,

Блатов Игорь Анатольевич, доктор физико-математических наук, профессор,

Россия

Кондратов Дмитрий Вячеславович, доктор физико-математических наук,

доцент, Россия

Лялькина Галина Борисовна, доктор физико-математических наук,

Малахов А В, доктор физико-математических наук, профессор, Украина Ворожбитова Александра Анатольевна, доктор филологических наук, профессор, Россия

Лыткина Лариса Владимировна, доктор филологических наук, доцент,

Россия Коваленко Елена Михайловна, доктор философских наук, профессор, Россия

Липич Тамара Ивановна, доктор философских наук, доцент, Россия

С

Россия

Стовпец А В , доктор философских наук, доцент, Украина

Антрапцева Надежда Михайловна, доктор химических наук, профессор,

Украина

Бажева Рима Чамаловна, доктор химических наук, профессор, Россия

Гризодуб Александр Иванович, доктор химических наук, профессор,

Ермагамбет Болат Толеуханович, доктор химических наук, профессор,

Максин Виктор Иванович, доктор химических наук, профессор, Украина Ангелова Поля Георгиева, доктор экономических наук, профессор, Болгария Безденежных Татьяна Ивановна, доктор экономических наук, профессор,

Бурда Алексей Григорьевич, доктор экономических наук, профессор, Россия Грановская

Дорохина Елена Юрьевна, доктор экономических наук, доцент, Россия Климова Наталья Владимировна, доктор экономических наук, профессор, Россия

Кочинев Юрий Юрьевич, доктор экономических наук, доцент, Россия Курмаев Петр Юрьевич, доктор экономических наук, профессор, Украина

Украина

Мельник Алён Алексеевна, доктор экономических наук, донент, Украина Миляева Лариса Григорьевна, доктор экономических наук, профессор,

Россия

Пахомова Елена Анатольевна, доктор экономических наук, доцент, Россия

Резников Андрей Валентинович, доктор экономических наук, доцент, Росси Савельева Нелли Александровна, доктор экономических наук, профессор,

Россия

Соколова Надежда Геннадьевна, доктор экономических наук, доцент, Россия Стрельцова Елена Дмитриевна, доктор экономических наук, доцент, Россия

Украина

Гетьман Анатолий Павлович, доктор юридических наук, профессор, Украина Кафарский Владимир Иванович, доктор юридических наук, профессор,

Украина

Кириченко Александр Анатольевич, доктор юридических наук, профессор,

Украина

Степенко Валерий Ефремович, доктор юридических наук, доцент, Россия

Тонков Евгений Евгеньевич, доктор юридических наук, профессор, Россия Шепитько Валерий Юрьевич, доктор юридических наук, профессор, Украина Яровенко Василий Васильевич, доктор юридических наук, профессор, Россия

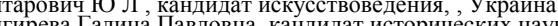

Волгирева Галина Павловна, кандидат исторических наук, доцент, Россия

Токарева Наталя Геннадъевна, кандидат медицинских наук, доцент, Россия

Демидова В Г, кандидат педагогических наук, доцент, Украина

Могилевская И М , кандидат педагогических наук, профессор, Украина

Лебедева Лариса Александровна, кандидат психологических наук, доцент,

Росеия

Украина

Стовпец В Г , кандидат филологических наук, доцент, Украина

Зубков Руслан Сергеевич, доктор экономических наук, доцент, Украин

Украина

Шарагов Василий Андреевич, доктор химических наук, доцент, Молдова 


\section{Редакційна Рада}

Бухаріна Ірина Леонідівна, доктор біологічних наук, професор, Росія Гребньова Надія Миколаївна, доктор біологічних наук, професор, Росія Гребньова Надія Миколаївна, доктор біологічних наук, професор, Росія Гриценко Світлана Анатоліївна, доктор біологічних наук, доцент, Росія Каленик Тетяна Кузьмівна, доктор біологічних наук, професор, Росія Князєва Ольга Олександрівна, доктор біологічних наук, доцент, Росія Кухар Олена Володимирівна, доктор біологічних наук, доцент, Казахстан Моісейкіна Людмила Гучаевна, доктор біологічних наук, професор, Росі Нефедьева Олена Едуардівна, доктор біологічних наук, доцент, Росія Сентябрьов Микола Миколайович, доктор біологічних наук, професор, Росія Стародубцев Володимир Михайлович, доктор біологічних наук, професор, Україна

Тестів Борис Вікторович, доктор біологічних наук, професор, Росія Тунгушбаева Зіна Байбагусовна, доктор біологічних наук, , Казахстан Фатєєва Надія Михайлівна, доктор біологічних наук, професор, Росія Ахмадієв Габдулахат Маликович, доктор ветеринарних наук, професор, Росі Шевченко Лариса Васигівна, доктор ветеринарних наук, професор, Україна Аніміца Євген Георгійович, доктор географічних наук, професор, Росія Сухова Марія Геннадіївна, доктор географічних наук, доцент, Росія Іухова Марія Геннадіїна, доктор географічних наук, доцент, Росія
Хлахула, доктор геолого-мінералогічних наук, професор, Чехія Федоришин Дмитро Дмитрович, доктор геолого-мінералогічних наук, професор, Україна

Кокебаева Гульжаухар Какеновна, доктор історичних наук, професор, Казахстан

Отепова Гульфира Елубаевна, доктор історичних наук, професор, Казахстан Тригуб Петро Микитович, доктор історичних наук, професор, Україна Елезовіч М Далібор, доктор історичних наук, доцент, Сербія Візир Вадим Анатолійович, доктор медичних наук, професор, Україна Федяніна Людмила Миколаївна, доктор медичних наук, професор, Росія Орлов Микола Михайлович, доктор наук з державного управління, доцент, Україна

Величко Степан Петрович, доктор педагогічних наук, професор, Україна Гавриленко Наталія Миколаївна, доктор педагогічних наук, доцент, Росія Дорофєєв Андрій Вікторович, доктор педагогічних наук, доцент, Росія Дорофєєв Андрій Вікторович, доктор педагогічних наук, доцент, Росія Марпова Наталія Костянтинівна, доктор педагогічних наук, професор, Росія
Мішеніна Тетяна Михайлівна, доктор педагогічних наук, професор, Україна Мішеніна Тетяна Михайлівна, доктор педагогічних наук, професор, У Растригіна Алла Миколаївна, доктор педагогічних наук, професор, Україна Сидорович Марина Михайлівна, доктор педагогічних наук, професор, Україна

Смирнов Євген Іванович, доктор педагогічних наук, професор, Росія Фатихова Алевтина Леонтіївна, доктор педагогічних наук, доцент, Росія Федотова Галина Олександрівна, доктор педагогічних наук, професор, Росія Ходакова Ніна Павлівна, доктор педагогічних наук, доцент, Росія Чигиринська Наталія В'ячеславівна, доктор педагогічних наук, професор, Росія

Чурекова Тетяна Михайлівна, доктор педагогічних наук, професор, Росія Латигіна Наталія Анатоліївна, доктор політологічних наук, професор,

\section{Україна}

Сирота Наум Михайлович, доктор політологічних наук, професор, Росія Хребіна Світлана Володимирівна, доктор психологічних наук, професор, Росія

Вожегова Раїса Анатоліївна, доктор сільськогосподарських наук, професор, Україна

Денисов Сергій Олександрович, доктор сільськогосподарських наук, професор, Росія

Жовтоног Ольга Ігорівна, доктор сільськогосподарських наук, , Україн Костенко Василь Іванович, доктор сільськогосподарських наук, професор, Україна

Котляров Володимир Владиславович, доктор сільськогосподарських наук, професор, Росія

Морозов Олексій Володимирович, доктор сільськогосподарських наук, професор, Україна

Патика Микола Володимирович, доктор сільськогосподарських наук, професор, Україна

Ребезов Максим Борисович, доктор сільськогосподарських наук, професор, Росія

Тараріко Юрій Олександрович, доктор сільськогосподарських наук, професор, Україн

Мальцева Анна Василівна, доктор соціологічних наук, доцент, Росія Стегній Василь Миколайович, доктор соціологічних наук, професор, Росія Тарасенко Лариса Вікторівна, доктор соціологічних наук, професор, Росія Аверченко Володимир Іванович, доктор технічних наук, професор, Росія Антонов Валерій Миколайович, доктор технічних наук, професор, Україна Биков Юрій Олександрович, доктор технічних наук, професор, Росія Гончарук Сергій Миронович, доктор технічних наук, професор, Росія Захаров Олег Володимирович, доктор технічних наук, професор, Росія Калайда Володимир Тимофійович, доктор технічних наук, професор, Росія Капітанів Василь Павлович, доктор технічних наук, професор, Україна Кирилова Олена Вікторівна, доктор технічних наук, доцент, Україна Кирилова Олена Вікторівна, доктор технічних наук, доцент, Украіна
Коваленко Петро Іванович, доктор технічних наук, професор, Україна Ковалей Богдан Володимирович, доктор технічних наук, професор, Україна Копей Богдан Володимирович, доктор технічних наук, професор,

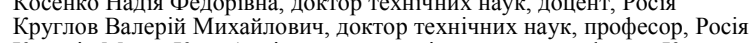
Круглов Валерій Михайлович, доктор технічних наук, професор, Росія
Кудерін Марат Крикбаевіч, доктор технічних наук, професор, Казахстан Кудерін Марат Крикбаевіч, доктор технічних наук, професор, Казахстан
Лебедєв Анатолій Тимофійович, доктор технічних наук, професор, Росія Ломотько Денис Вікторович, доктор технічних наук, професор, Україна Макарова Ірина Вікторівна, доктор технічних наук, професор, Росія Морозова Тетяна Юріївна, доктор технічних наук, професор, Росія Павленко Анатолій Михайлович, доктор технічних наук, професор, Україна Парунакян Ваагн Емільович, доктор технічних наук, професор, Україна Пачурін Герман Васильович, доктор технічних наук, професор, Росія
Першин Володимир Федорович, доктор технічних наук, професор, Росія

Піганов Михайло Миколайович, доктор технічних наук, професор, Росія

Поляков Андрій Павлович, доктор технічних наук, професор, Україна

Попов Віктор Сергійович, доктор технічних наук, професор, Росія Рокочінскій Анатолій Миколайович, доктор технічних наук, професор, Україна

Ромащенко Михайло Іванович, доктор технічних наук, професор, Україна Семенцов Георгій Никифорович, доктор технічних наук, професор, Україна Сухенко Юрій Григорович, доктор технічних наук, професор, Україна Устенко Сергій Анатолійович, доктор технічних наук, доцент, Україна Хабібуллін Рифат Габдулхакович, доктор технічних наук, професор, Росія Червоний Іван Федорович, доктор технічних наук, професор, Україна Шайко-Шайковскій Олександр Геннадійович, доктор технічних наук, професор, Україна

Щербань Ігор Васильович, доктор технічних наук, доцент, Росія

Бушуєва Інна Володимирівна, доктор фармацевтичних наук, професор,

Україна

Волох Дмитро Степанович, доктор фармацевтичних наук, професор, Україна Георгієвський Геннадій Вікторович, доктор фармацевтичних наук, старший науковий співробітник, Україна

Гудзенко Олександр Павлович, доктор фармацевтичних наук, професор, Україна

Тихонов Олександр Іванович, доктор фармацевтичних наук, професор,

Україна

Шаповалов Валерій Володимирович, доктор фармацевтичних наук,

професор, Україна

Шаповалова Вікторія Олексіївна, доктор фармацевтичних наук, професор,

Україна

Блатов Ігор Анатолійович, доктор фізико-математичних наук, професор,

Росія

Кондратов Дмитро В'ячеславович, доктор фізико-математичних наук, доцент,

Росія

Лялькіна Галина Борисівна, доктор фізико-математичних наук, професор,

Росія

Малахов А В , доктор фізико-математичних наук, професор, Україна

Ворожбітова Олександра Анатоліївна, доктор філологічних наук, професор, Росія

Литкіна Лариса Володимирівна, доктор філологічних наук, доцент, Росія Попова Таїсія Георгіївна, доктор філологічних наук, професор, Росія Коваленко Олена Михайлівна, доктор філософських наук, професор, Росія Липич Тамара Іванівна, доктор філософських наук, доцент, Росія Майданюк Ірина Зіновіївна, доктор філософських наук, доцент, Україна Светлов Віктор Олександрович, доктор філософських наук, професор, Росія Стовпец А В , доктор філософських наук, доцент, Україна

Антрапцева Надія Михайлівна, доктор хімічних наук, професор, Україна Бажев Риму Чамаловна, доктор хімічних наук, професор, Росія Гризодуб Олександр Іванович, доктор хімічних наук, професор, Україна Ермагамбет Болат Толеухановіч, доктор хімічних наук, професор, Казахстан Максін Віктор Іванович, доктор хімічних наук, професор, Україна

Ангелова Поля Георгієва, доктор економічних наук, професор, Болгарія Ангелова Поля Георгієва, доктор економічних наук, професор, Болгарія Бурда Олексій Григорович, доктор економічних наук, професор, Росія Бурда Олексій Григорович, доктор економічних наук, професор, Росія

Грановська Людмила Миколаївна, доктор економічних наук, проф
Україна
Дорохіна Олена Юріївна, доктор економічних наук, доцент, Росія Климова Наталія Володимирівна, доктор економічних наук, професор, Росія Кочинев Юрій Юрійович, доктор економічних наук, доцент, Росія Курман Петро Юрійович, доктор економічних наук, професор, Україна Лапкіна Інна Олександрівна, доктор економічних наук, професор, Україн Мельник Олена Олексіївна, доктор економічних наук, доцент, Україна Міляєва Лариса Григорівна, доктор економічних наук, професор, Росія Пахомова Олена Анатоліївна, доктор економічних наук, доцент, Росія Резніков Андрій Валентинович, доктор економічних наук, доцент, Росія Савельєва Неллі Олександрівна, доктор економічних наук, професор, Росія Соколова Надія Геннадіївна, доктор економічних наук, доцент, Росія Стрельцова Олена Дмитрівна, доктор економічних наук, доцент, Росія Стрельцова Олена Дмитрівна, доктор економічних наук, доцент, Росія
Батиргареева Владислава Станіславовона, доктор юридичних наук, , Україна Батиргареева Владислава Станіславовона, доктор юридичних наук, , Укра Гетьман Анатолій Павлович, доктор юридичних наук, професор, Укра Україна

Кириченко Олександр Анатолійович, доктор юридичних наук, професор,

Україна

Степенко Валерій Єфремович, доктор юридичних наук, доцент, Росія

Тонков Євген Євгенович, доктор юридичних наук, професор, Росія

Шепітько Валерій Юрійович, доктор юридичних наук, професор, Україна

Шишка Роман Богданович, доктор юридичних наук, професор, Україна

Яровенко Василь Васильович, доктор юридичних наук, професор, Росія

Кантаровіч Ю Л , кандидат мистецтвознавства, , Україна

Волгірева Галина Павлівна, кандидат історичних наук, доцент, Росія

Токарєва Наталія Геннадіївна, кандидат медичних наук, доцент, Росія

Докарєва Наталія Геннадівна, кандидат медичних наук, доце
Демидова В Г, кандидат педагогічних наук, доцент, Україна

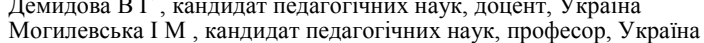

Могилевська I M , кандидат педагогічних наук, професор, Україна
Лебедєва Лариса Олександрівна, кандидат психологічних наук, доцент, Росія

Лебедєва Лариса Олександрівна, кандидат психологічних наук, доцент, Росія
Шаповалов Валентин Валерійович, кандидат фармацевтичних наук, доцент,

Україна

Стовпец В Г , кандидат філологічних наук, доцент, Україна

Зубков Руслан Сергійович, доктор економічних наук, доцент, Україна

Толбатов Андрій Володимирович, кандидат технічних наук, доцент, Україна

Шарагов Василь Андрійович, доктор хімічних наук, доцент, Молдова 


\section{Editorial board}

Bukharina Irina Leonidovna, Doctor of Biological Sciences, Professor, Russia Grebneva Nadezhda Nikolayevna, Doctor of Biological Sciences, Professor, Russia

Gritsenko Svetlana Anatol'yevna, Doctor of Biological Sciences, assistan

professor, Russia Kalenik Tat'yana Kuz'minichna, Doctor of Biological Sciences, Professor, Russia Knyazeva Ol'ga Aleksandrovna, Doctor of Biological Sciences, assistant professor,

Kukhar Yelena Vladimirovna, Doctor of Biological Sciences, assistant professor, Kazakhstan

Moiseykina Lyudmila Guchayevna, Doctor of Biological Sciences, Professor,

Nefed'yeva Yelena Eduardovna, Doctor of Biological Sciences, assistant professor,

Sentyabrev Nikolay Nikolayevich, Doctor of Biological Sciences, Professor,

Russia

Starodubtsev Vladimir Mikhaylovich, Doctor of Biological Sciences, Professor,

Ukraine

ungushbayeva Zina Baybagusovna, Doctor of Biological Sciences, , Kazakhstan

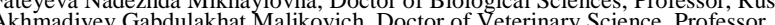

Russia

Shevchenko Larisa Vasil'yevna, Doctor of Veterinary Science, Professor, Ukraine Animitsa Yevgeniy Georgiyevich, Doctor of Geographical Sciences, Professor,

Russia

Sukhova Mariya Gennad'yevna, Doctor of Geographical Sciences, assistant

professor, Russia

rzhi Khlakhula, Doctor of Geological and Mineralogical Sciences, Professor, Czech Republic

Fedorishin Dmitro Dmitrovich, Doctor of Geological and Mineralogical Sciences,

ul'zhaukhar Kakenovna, Doctor of Historical Sciences, Professor,

Otepova Gur

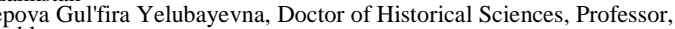

Trigub Petr Nikitovich, Doctor of Historical Sciences, Professor, Ukraine Elezovich M Dalibor, Doctor of Historical Sciences, assistant professor, Serbia Vizir Vadim Anatol'yevich, Doctor of Medical Sciences, Professor, Ukraine Fedyanina Lyudmila Nikolayevna, Doctor of Medical Sciences, Professor, Russia Orlov Nikolay Mikhaylovich, Doctor of Science in Public Administration, assistant rofessor, Ukrain

Velichko Stepan Petrovich, doctor of pedagogical sciences, Professor, Ukraine Gavrilenko Nataliya Nikolayevna, doctor of pedagogical sciences, assistant Gilev Gennadiy Andreyevich, doctor of pedagogical sciences, Professor, Russia Dorofeyev Andrey Viktorovich, doctor of pedagogical sciences, assistant professor, Russia

Karpova Nataliya Konstantinovna, doctor of pedagogical sciences, Professor,

Russia

Mishenina Tat'yana Mikhaylovna, doctor of pedagogical sciences, Professor,

Ukraine

Nikolayeva Alla Dmitriyevna, doctor of pedagogical sciences, Professor, Russia Rastrygina Alla Nikolayevna, doctor of pedagogical sciences, Professor, Ukrain Sidorovich

Smirnov Yevgeniy Ivanovich, doctor of pedagogical sciences, Professor, Russia Fatykhova Alevtina Leont'yevna, doctor of pedagogical sciences, assistant

professor, Russia

Fedotova Galina Aleksandrovna, doctor of pedagogical sciences, Professor, Russia Khodakova Nina Pavlovna, doctor of pedagogical sciences, assistant professor, Russia

Chigirinskaya Natal'ya Vyacheslavovna, doctor of pedagogical sciences, Professor,

Churekova Tat'yana Mikhaylovna, doctor of pedagogical sciences, Professor,

Russia

Latygina Natal'ya Anatol'yevna, Doctor of Political Sciences, Professor, Ukraine Sirota Naum Mikhaylovich, Doctor of Political Sciences, Professor, Russia Vozhegova Raisa Anatol'yevna, doctor of agricultural sciences, Professor, Ukraine Denisov Sergey Aleksandrovich, doctor of agricultural sciences, Professor, Russia Zhovtonog Ol'ga Igorevna, doctor of agricultural sciences, , Ukraine Kostenko Vasiliy lvanovich, doctor of agricultural sciences, Professor, Ukraine Kotlyarov Vladimir Vladislavovich, doctor of agricultural sciences, Professor, Russia

Morozov Aleksey Vladimirovich, doctor of agricultural sciences, Professor,

Uraine

Patyka Nikolay Vladimirovich, doctor of agricultural sciences, Professor, Ukraine Rebezov Maksim Borisovich, doctor of agricultural sciences, Professor, Russia

Tarariko Yuriy Aleksandrovich, doctor of agricultural sciences, Professor, Ukraine Mal'tseva Anna Vasil'yevna, Doctor of Sociology, assistant professor, Russia

Stegniy Vasiliy Nikolayevich, Doctor of Sociology, Professor, Russia

Averchenkov Vladimir Ivanovich, Doctor of Technical Sciences, Professor, Russia Antonov Valeriy Nikolayevich, Doctor of Technical Sciences, Professor, Ukraine Bykov Yuriy Aleksandrovich, Doctor of Technical Sciences, Professor, Russia Goncharuk Sergey Mironovich, Doctor of Technical Sciences, Professor, Russia Zars Kayda Vladimir Timofeyevich, Doctor of Technical Sciences, Professor, Russ Viktorovna, Doctor of Technical Sciences, assistant professor, Ukraine

Kovalenko Petr Ivanovich, Doctor of Technical Sciences, Professor, Ukraine Kopey Bogdan Vladimirovich, Doctor of Technical Sciences, Professor, Ukraine Kosenko Nadezhda Fedorovna, Doctor of Technical Sciences, assistant professor

Russia
Kruglov Valeriy Mikhaylovich, Doctor of Technical Sciences, Professor, Russia Kuderin Marat Krykbayevich, Doctor of Technical Sciences, Professor,

Kazakhstan Lebedev Anatoliy Timofeyevich, Doctor of Technical Sciences, Professor, Rus Makarova Irina Viktorovna, Doctor of Technical Sciences, Professor, Russia Makarova Irina Viktorovna, Doctor of Technical Sciences, Professor, Russia Pavlenko Anatoliy Mikhaylovich, Doctor of Technical Sciences, Professor, Ukraine

Parunakyan Vaagn Emil'yevich, Doctor of Technical Sciences, Professor, Ukrain Pachurin German Vasil'yevich, Doctor of Technical Sciences, Professor, Russia Pershin Vladimir Fedorovich, Doctor of Technical Sciences, Professor, Russia Piganov Mikhail Nikolayevich, Doctor of Technical Sciences, Professor, Russia Polyakov Andrey Pavlovich, Doctor of Technical Sciences, Professor, Úkraine Popov Viktor Sergeyevich, Doctor of Technical Sciences, Professor, Russia

Ukraine

Romashchenko Mikhail Ivanovich, Doctor of Technical Sciences, Professor,

Ukraine

Sementsov Georgiy Nikiforovich, Doctor of Technical Sciences, Professor,

Skraine
Sukhenko Yuriy Grigor'yevich, Doctor of Technical Sciences, Professor, Ukraine

\section{Ustenko S}

Russia

Chervonyy Ivan Fedorovich, Doctor of Technical Sciences, Professor, Ukraine Shayko-Shaykovskiy Aleksandr Gennad'yevich, Doctor of Technical Sciences,

Shibayev Aleksandr Grigor'yevich, Doctor of Technical Sciences, Professor,

Shraine

Russia

Bushuyeva Inna Vladimirovna, Doctor of Pharmaceutical Sciences, Professor,

Ukraine

Volokh Dmitriy Stepanovich, Doctor of Pharmaceutical Sciences, Professor,

Gkraine Researcher, Ukraine

Gudzenko Aleksandr Pavlovich, Doctor of Pharmaceutical Sciences, Professor,

Ukraine

Thonov Aleksandr Ivanovich, Doctor of Pharmaceutical Sciences, Professor,

Ukraine

Ukraine

Shapovalova Viktoriya Alekseyevna, Doctor of Pharmaceutical Sciences,
Professor, Ukraine

Blatov Igor' Anatol'yevich, Doctor of Physical and Mathematical Sciences,

Professor, Russia

Kondratov Dmitriy Vyacheslavovich, Doctor of Physical and Mathematical Sciences, assistant professor, Russia

Lyal'kina Galina Borisovna, Doctor of Physical and Mathematical Sciences, Professor, Russia

V, Doctor of Physical and Mathematical Sciences, Professor,

Vkraine Lytkina Larisa Vladimirovna, doctor of philology, assistant professor, Russia Kovalenko Yelena Mikhaylovna, doctor of philosophical science, Professor,

Russia

Lipich Tamara Ivanovna, doctor of philosophical science, assistant professor,

Maydanyuk Irina Zinoviyevna, doctor of philosophical science, assistant professor,

Svetlov Viktor Aleksandrovich, doctor of philosophical science, Professor, Russia Stovpets A V , doctor of philosophical science, assistant professor, Ukraine

Ukraine

Bazheva Rima Chamalovna, Doctor of Chemical Sciences, Professor, Russia Grizodub Aleksandr Ivanovich, Doctor of Chemical Sciences, Professor, Ukrain Yermagambet Bolat Toleukhanovich, Doctor of Chemical Sciences, Professor,

Kazakhstan Angelova Polya Georgiyeva, Doctor of Economic Sciences, Professor, Bulgari

Rursia Aleksey Grigor'yevich, Doctor of Economic Sciences, Professor, Russia Granovskaya Lyudmila Nikolayevna, Doctor of Economic Sciences, Professor,

Dorokhina Yelena Yur'yevna, Doctor of Economic Sciences, assistant professor,

Russia

Klimova Natal'ya Vladimirovna, Doctor of Economic Sciences, Professor, Russia

Kochinev Yuriy Yur'yevich, Doctor of Economic Sciences, assistant professor,

Russia

Kurmayev Petr Yur'yevich, Doctor of Economic Sciences, Professor, Ukraine

Mel'nik Alona Alekseyevna, Doctor of Economic Sciences, assistant professor,

Ukraine

Milyayeva Larisa Grigor'yevna, Doctor of Economic Sciences, Professor, Russia

Pakhomova Yelena Anatol'yevna, Doctor of Economic Sciences, assistant

Reznikov Andrey

Savel'yeva Nelli Aleksandrovna, Doctor of Economic Sciences, Professor, Russi Sokolova Nadezhda Gennad'yevna, Doctor of Economic Sciences, assistan

professor, Russia Russia

Batyrgareyeva Vladislava Stanislavovona, doctor of law, , Ukraine

Get'man Anatoliy Pavlovich, doctor of law, Professor, Ukraine

Kafarskiy Vladimir Ivanovich, doctor of law, Professor, Ukraine

Stepenko Valeriy Yefremovich, doctor of law, assistant professor, Russia

Tonkov Yevgeniy Yevgen'yevich, doctor of law, Professor, Russia

Shepit'ko Valeriy Yur'yevich, doctor of law, Professor, Ukraine

Shishka Roman Bogdanovich, doctor of law, Professor, Ukraine

Yarovenko Vasiliy Vasil'yevich, doctor of law, Professor, Russia

Kantarovich YU L , Ph D in History of Arts, , Ukraine

Volgireva Galina Pavlovna, Candidate of Historical Sciences, assistant professor,

Russia

professor, Russia

professor, Russia

Demidova V G , Candidate of Pedagogical Sciences, assistant professor, Ukraine Mogilevskaya I M , Candidate of Pedagogical Sciences, Professor, Ukraine Lebedeva Larisa Aleksandrovna, Candidate of Psychological Sciences, assistant

Yatsenko Oleksandr Volodymyrovych, Candidate of Technical Sciences, Professor, Ukrain

Shapovalov Valentin Valer'yevich, Candidate of Pharmaceutical Sciences,

assistant professor, Ukraine

Ruslan Zubkov, Doctor of Economics, Associate Professor, Ukraine

Thatov Andrey Vladimirovich, candidate of technical sciences, associate

professor, Ukraine

Sharagov Vasily Andreevich, Doctor of Chemistry, Associate Professor, Moldova 


\section{О журнале}

Международный научный периодический журнал "Научный взгляд в будущее" получил большое признание среди отечественных и зарубежных интеллектуалов. Сегодня в журнале публикуются авторы из России, Украины, Молдовы, Казахстана, Беларуси, Чехии, Болгарии, Литвы Польши и других государств.

Учрежден в 2015 году. Периодичность выхода: ежеквартально.

Основными целями журнала "Научный взгляд в будущее" являются:

- содействие обмену знаниями в научном сообществе;

- помощь молодым ученым в информировании научной общественности об их научных достижениях;

- создание основы для инноваций и новых научных подходов, а также открытий в неизвестных областях;

- содействие объединению профессиональных научных сил и формирование нового поколения ученыхспециалистов в разных сферах.

Журнал целенаправленно знакомит читателя с оригинальными исследованиями авторов в различных областях науки, лучшими образцами научной публицистики.

Публикации журнала "Научный взгляд в будущее" предназначены для широкой читательской аудитории - всех тех, кто любит науку. Материалы, публикуемые в журнале, отражают актуальные проблемы и затрагивают интересы всей общественности.

Каждая статья журнала включает обобщающую информацию на английском языке.

Журнал зарегистрирован в РИНЦ SCIENCE INDEX и INDEXCOPERNICUS.

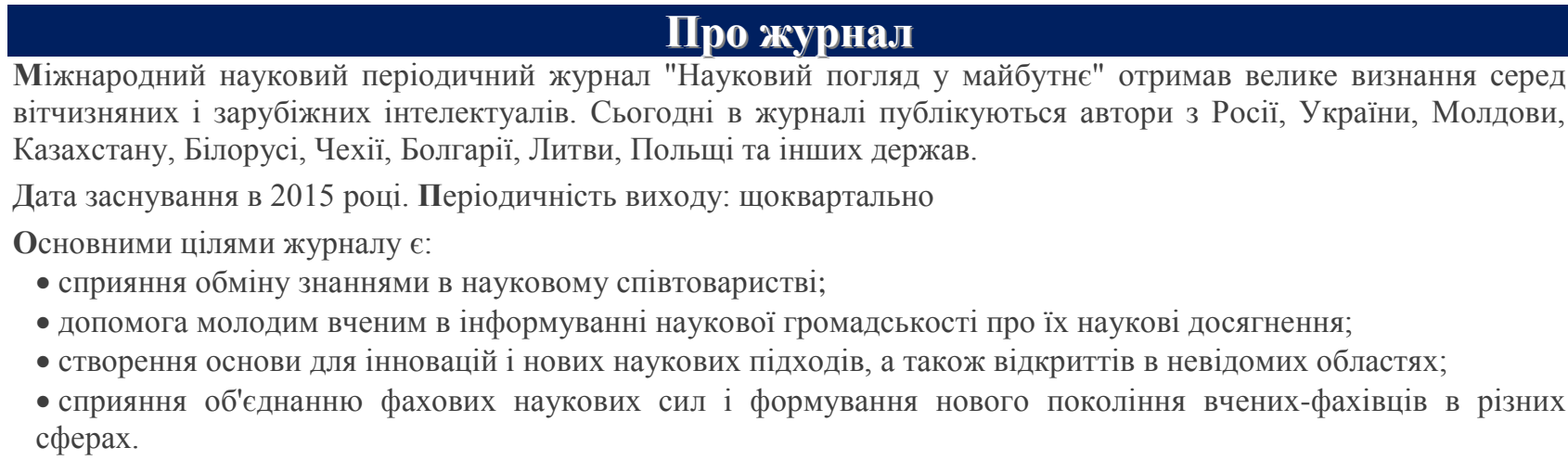

Журнал цілеспрямовано знайомить читача з оригінальними дослідженнями авторів в різних областях науки, кращими зразками наукової публіцистики.

Публікації журналу призначені для широкої читацької аудиторії - усіх тих, хто любить науку. Матеріали, що публікуються в журналі, відображають актуальні проблеми і зачіпають інтереси всієї громадськості.

Кожна стаття журналу включає узагальнюючу інформацію англійською мовою.

Журнал зареєстрований в РИНЦ SCIENCE INDEX i INDEXCOPERNICUS.

\section{About the journal}

The International Scientific Periodical Journal "Scientific look into the future" has gained considerable recognition among domestic and foreign researchers and scholars. Today, the journal publishes authors from Russia, Ukraine, Moldova, Kazakhstan, Belarus, Czech Republic, Bulgaria, Lithuania, Poland and other countries.

Journal Established in 2015. Periodicity of publication: Quarterly

The journal activity is driven by the following objectives:

- Broadcasting young researchers and scholars outcomes to wide scientific audience

- Fostering knowledge exchange in scientific community

- Promotion of the unification in scientific approach

- Creation of basis for innovation and new scientific approaches as well as discoveries in unknown domains

The journal purposefully acquaints the reader with the original research of authors in various fields of science, the best examples of scientific journalism.

Publications of the journal are intended for a wide readership - all those who love science. The materials published in the journal reflect current problems and affect the interests of the entire public.

Each article in the journal includes general information in English.

The journal is registered in the RISC SCIENCE INDEX and INDEXCOPERNICUS. 


\section{Требования к статьям}

Статьи должны соответствовать тематическому профилю журнала, отвечать международным стандартам научных публикаций и быть оформленными в соответствии с установленными правилами. Они также должны представлять собой изложение результатов оригинального авторского научного исследования, быть вписанными в контекст отечественных и зарубежных исследований по этой тематике, отражать умение автора свободно ориентироваться в существующем библиографическом контексте по затрагиваемым проблемам и адекватно применять общепринятую методологию постановки и решения научных задач.

Все тексты должны быть написаны литературным языком, отредактированы и соответствовать научному стилю речи. Некорректность подбора и недостоверность приводимых авторами фактов, цитат, статистических и социологических данных, имен собственных, географических названий и прочих сведений может стать причиной отклонения присланного материала (в том числе - на этапе регистрации).

Все таблицы и рисунки в статье должны быть пронумерованы, иметь заголовки и ссылки в тексте. Если данные заимствованы из другого источника, на него должна быть дана библиографическая ссылка в виде примечания.

Название статьи, ФИО авторов, учебные заведения (кроме основного языка текста) должны быть представлены и на английском языке.

Статьи должны сопровождаться аннотацией и ключевыми словами на языке основного текста и обязательно на английском языке. Аннотация должна быть выполнена в форме краткого текста, который раскрывает цель и задачи работы, ее структуру и основные полученные выводы. Аннотация представляет собой самостоятельный аналитический текст и должна давать адекватное представление о проведенном исследовании без необходимости обращения к статье. Аннотация на английском (Abstract) должна быть написана грамотным академическим языком.

Приветствуется наличие УДК, ББК, а также (для статей по Экономике) код JEL (https://www.aeaweb.org/jel/guide/jel.php) Принятие материала к рассмотрению не является гарантией его публикации. Зарегистрированные статьи рассматриваются редакцией и при формальном и содержательном соответствии требованиям журнала направляются на экспертное рецензирование, в том числе через открытое обсуждение с помощью веб-ресурса www.sworld.education.

В журнале могут быть размещены только ранее неопубликованные материалы.

\section{Вимоги до статей}

Статті повинні відповідати тематичному профілю журналу, відповідати міжнародним стандартам наукових публікацій бути оформленими відповідно до встановлених правил. Вони також повинні представляти собою виклад результатів оригінального авторського наукового дослідження, бути вписаними в контекст вітчизняних і зарубіжних досліджень 3 цієї тематики, відображати вміння автора вільно орієнтуватися в існуючому бібліографічному контексті по піднятим проблемам і адекватно застосовувати загальноприйняту методологію постановки і вирішення наукових завдань.

Всі тексти повинні бути написані літературною мовою, відредаговані і відповідати науковому стилю мовлення.

Некоректність підбору і недостовірність наведених авторами фактів, цитат, статистичних та соціологічних даних, власних імен, географічних назв та інших відомостей може стати причиною відхилення надісланого матеріалу (в тому числі - на етапі реєстрації).

Всі таблиці і рисунки в статті повинні бути пронумеровані, мати заголовки і посилання в тексті. Якщо дані запозичені 3 іншого джерела, на нього повинні бути бібліографічні посилання у вигляді примітки.

Назва статті, ПІБ авторів, навчальні заклади (крім основної мови тексту) повинні бути представлені і на англійській мові.

Статті повинні супроводжуватися анотацією та ключовими словами на мові основного тексту і обов'язково англійською мовою. Анотація повинна бути виконана у формі короткого тексту, який розкриває мету і завдання роботи, іiі структуру та основні отримані висновки. Анотація представляе собою самостійний аналітичний текст і повинна давати адекватне уявлення про проведене дослідження без необхідності звернення до статті. Анотація англійською (Abstract) повинна бути написана грамотною академічною мовою.

Заохочується наявність УДК, ББК, а також (для статей по Економіці) код JEL (https://www.aeaweb.org/jel/guide/jel.php) Ухвалення матеріалу до розгляду не є гарантією його публікації. Зареєстровані статті розглядаються редакцією і при формальному і змістовному відповідно до вимог журналу направляються на експертне рецензування, в тому числі через відкрите обговорення за допомогою веб-ресурсу www.sworld.education.

У журналі можуть бути розміщені тільки раніше неопубліковані матеріали.

\section{Requirements for articles}

Articles should correspond to the thematic profile of the journal, meet international standards of scientific publications and be formalized in accordance with established rules. They should also be a presentation of the results of the original author's scientific research, be inscribed in the context of domestic and foreign research on this topic, reflect the author's ability to freely navigate in the existing bibliographic context on the problems involved and adequately apply the generally accepted methodology of setting and solving scientific problems.

All texts should be written in literary language, edited and conform to the scientific style of speech. Incorrect selection and unreliability of the facts, quotations, statistical and sociological data, names of own, geographical names and other information cited by the authors can cause the rejection of the submitted material (including at the registration stage).

All tables and figures in the article should be numbered, have headings and links in the text. If the data is borrowed from another source, a bibliographic reference should be given to it in the form of a note.

The title of the article, the full names of authors, educational institutions (except the main text language) should be presented in English.

Articles should be accompanied by an annotation and key words in the language of the main text and must be in English. The abstract should be made in the form of a short text that reveals the purpose and objectives of the work, its structure and main findings. The abstract is an independent analytical text and should give an adequate idea of the research conducted without the need to refer to the article. Abstract in English (Abstract) should be written in a competent academic language.

The presence of UDC, BBK

Acceptance of the material for consideration is not a guarantee of its publication. Registered articles are reviewed by the editorial staff and, when formally and in substance, the requirements of the journal are sent to peer review, including through an open discussion using the web resource www.sworld.education

Only previously unpublished materials can be posted in the journal. 
Положение об этике публикации научных данных и ее нарушениях

Редакция журнала осознает тот факт, что в академическом сообществе достаточно широко распространены случаи нарушения этики публикации научных исследований. В качестве наиболее заметных и вопиющих можно выделить плагиат, направление в журнал ранее опубликованных материалов, незаконное присвоение результатов чужих научных исследований, а также фальсификацию данных. Мы выступаем против подобных практик.

Редакция убеждена в том, что нарушения авторских прав и моральных норм не только неприемлемы с этической точки зрения, но и служат преградой на пути развития научного знания. Потому мы полагаем, что борьба с этими явлениями должна стать целью и результатом совместных усилий наших авторов, редакторов, рецензентов, читателей и всего академического сообщества. Мы призываем всех заинтересованных лиц сотрудничать и участвовать в обмене информацией в целях борьбы с нарушением этики публикации научных исследований.

Со своей стороны редакция готова приложить все усилия к выявлению и пресечению подобных неприемлемых практик. Мы обещаем принимать соответствующие меры, а также обращать пристальное внимание на любую предоставленную нам информацию, которая будет свидетельствовать о неэтичном поведении того или иного автора.

Обнаружение нарушений этики влечет за собой отказ в публикации. Если будет выявлено, что статья содержит откровенную клевету, нарушает законодательство или нормы авторского права, то редакция считает себя обязанной удалить ее с веб-ресурса и из баз цитирования. Подобные крайние меры могут быть применены исключительно при соблюдении максимальной открытости и публичности.

\section{Положення про етику публікації наукових даних і ії порушеннях}

Редакція журналу усвідомлює той факт, що в академічній спільноті досить широко поширені випадки порушення етики публікації наукових досліджень. В якості найбільш помітних можна виділити плагіат, відправлення в журнал раніше опублікованих матеріалів, незаконне привласнення результатів чужих наукових досліджень, а також фальсифікацію даних. Ми виступаємо проти подібних практик.

Редакція переконана в тому, що порушення авторських прав і моральних норм не тільки неприйнятні з етичної точки зору, але і служать перешкодою на шляху розвитку наукового знання. Тому ми вважаємо, що боротьба 3 цими явищами повинна стати метою і результатом спільних зусиль наших авторів, редакторів, рецензентів, читачів і усієї академічної спільноти. Ми закликаємо всіх зацікавлених осіб співпрацювати і брати участь в обміні інформацією з метою боротьби з порушенням етики публікації наукових досліджень.

3і свого боку редакція готова докласти всіх зусиль до виявлення та припинення подібних неприйнятних практик. Ми обіцяємо вживати відповідних заходів, а також звертати пильну увагу на будь-яку надану нам інформацію, яка буде свідчити про неетичну поведінку того чи іншого автора.

Виявлення порушень етики тягне за собою відмову в публікації. Якщо буде виявлено, що стаття містить відвертий наклеп, порушує законодавство або норми авторського права, то редакція вважає себе зобов'язаною видалити іiі з веб-ресурсу і з баз цитування. Подібні крайні заходи можуть бути застосовані виключно при дотриманні максимальної відкритості і публічності.

\section{Regulations on the ethics of publication of scientific data and its violations}

The editors of the journal are aware of the fact that in the academic community there are quite widespread cases of violation of the ethics of the publication of scientific research. As the most notable and egregious, one can single out plagiarism, the posting of previously published materials, the misappropriation of the results of foreign scientific research, and falsification of data. We oppose such practices.

The editors are convinced that violations of copyrights and moral norms are not only ethically unacceptable, but also serve as a barrier to the development of scientific knowledge. Therefore, we believe that the fight against these phenomena should become the goal and the result of joint efforts of our authors, editors, reviewers, readers and the entire academic community. We encourage all stakeholders to cooperate and participate in the exchange of information in order to combat the violation of the ethics of publication of scientific research.

For its part, the editors are ready to make every effort to identify and suppress such unacceptable practices. We promise to take appropriate measures, as well as pay close attention to any information provided to us, which will indicate unethical behavior of one or another author.

Detection of ethical violations entails refusal to publish. If it is revealed that the article contains outright slander, violates the law or copyright rules, the editorial board considers itself obliged to remove it from the web resource and from the citation bases. Such extreme measures can be applied only with maximum openness and publicity. 


\title{
УДК 664.38:664.95
}

\section{METHOD OF PRODUCTION GELATINE BASED ON FRESHWATER FISH СПОСІБ ВИРОБНИЦТВА ЖЕЛАТИНУ НА ОСНОВІ ПРІСНОВОДНОЇ РИБНОЇ СИРОВИНИ}

\author{
Ivanyta A.O./ Іванюта A.O.
}

c.t.s., assistant / к.m.н., асистент. National University of Bioresources and Environmental Sciences of Ukraine Ukraine, Kyiv, Heroes Oborony, 15, 03041 Національний університет біоресурсів і природокористування України, Україна, Київ, вул. Героїв Оборони, 15, 03041

Nesterenko N.A/ Нестеренко Н. А. Applicant /здобувач.

Kyiv National University of Trade and Economics 19 Kioto Str., 02156Kyiv, Ukraine Київський національний торговельно-економічний університет, Україна, Київ, вул. Кіото 19, 02156

Анотація. В статті розглянуто перспективні напрямки переробки білого амура. Наведено відомі способи виробництва рибного желатину та проаналізовано їх недоліки. Представлено результати фізико-хімічних показників та хімічного складу рибного желатину на основі білого амура.

Ключові слова: спосіб виробництва, желатин, прісноводна риба, фізико-хімічні показники.

Одним із основних шляхів ефективного використання рибних ресурсів $\epsilon$ переробка малоцінної рибної сировини, що утворюється після їх обробки.

Перспективним напрямом переробки колагеновмісної сировини 3 білого амура є виробництво рибного желатину. Моніторинг сучасних тенденцій ринку желатину свідчить про його обмежений асортимент, найпоширенішим серед яких є желатин тваринного походження. Проте у зв'язку з масовими випадками захворювань великої рогатої худоби, використання колагену тваринного походження є небезпечним.

Відповідно, на даний час актуальним є питанням розробки желатину на основі малоцінної рибної сировини з білого амура, що сприятиме розширенню асортименту якісного та конкурентоспроможного желатину.

Науковцями запропоновано технологію виробництва желатину на основі шкіри риб, що включає можливість використання аноліта ЕXA 3 різними значеннми рН, від 2,0 до 5,0 для екстракції колагеновмісної сировини протягом 0,5 - 4 годин, при температурі $45^{\circ} \mathrm{C}-65^{\circ} \mathrm{C}$, сушіння екстракту конвективним методом в сушильній шафі 3 циркуляцією повітря при температурі $18-22{ }^{\circ} \mathrm{C}, 3$ відносною вологістю повітря 55-60\% протягом 18-24 годин [1].

Даний спосіб висушування характеризується відносно низьким коефіцієнтом корисної дії, що обумовлюється низькою відносною вологістю і впливає на тривалість технологічного процесу та якість готового продукту.

Найбільш близьким аналогом до запропонованого способу $\epsilon$ спосіб виробництва рибного желатину, що передбачає промивку рибних відходів, їх варіння $з$ додаванням молочної сироватки у співвідношенні 1,0:0,5-2,5 протягом 
40-90 хвилин при температурі кипіння і відділенні рідкої фази. Тверду частину після першого варіння додатково піддають двом наступним варінням. Після кожного етапу варіння відділяють жир від рідкої фази. Рідкі фази після трьох послідовних варок змішують, фільтрують для відділення дрібних частинок. [2].

Недоліком даного способу є недостатній час термічної обробки, оскільки при вказаних режимах відбувається не повний перехід білкових речовин в бульйон, що може негативно впливати на міцність та в'язкість готової продукції.

Використання запропонованого способу виробництва дозволить отримати наступний результат: забезпечити та підвищити ефективність використання ресурсного потенціалу вітчизняного рибогосподарського комплексу, що можливе за умов раціонального використання риби внутрішніх водойм країни; розширити асортимент желатину вітчизняного виробництва; підвищити біологічну цінність та споживні властивості желатину.

Основними компонентами створюваного продукту $\epsilon$ голови i кістки прісноводної риби - білого амура. Результати досліджень біохімічних властивостей голів та кісток білого амура підтвердили можливість їх комплексного використання для виробництва ефективного рибного желатину.

Процес виробництва рибного желатину на основі голів та кісток прісноводної риби - білого амура складається з таких послідовних процесів: підготовка рибної сировини, подрібнення, варіння, фільтрування, висушування, пакування, маркування, зберігання.

Рибну сировину промивали проточною водою ( $\mathrm{t}$ води $18-20^{\circ} \mathrm{C}$ ), подрібнювали на риборізці до розміру 1-2 см, змішували та дозували компоненти (вода і рибна сировина) у співвідношенні 1:1, варили в парових котлах варильниках 2 години при температурі $100^{\circ} \mathrm{C}$, фільтрували та піддавали сублімаційному сушінню протягом 14 годин при температурі $\left(-70{ }^{\circ} \mathrm{C}\right)$. Готовий рибний желатин запаковували в паперові тришарові крафт - мішки i зберігали в сухому прохолодному місці при температурі $22 \pm 2{ }^{\circ} \mathrm{C}$ та відносній вологості повітря не більше 70\% протягом 15 місяців.

Про позитивний результат запропонованого нами способу виробництва желатину на основі прісноводної рибної сировини свідчать дані хімічного складу та фізико-хімічні показники якості готового продукту (табл.1, 2).

Таблиця 1

Фізико-хімічні показники якості желатину на основі прісноводної рибної сировини

\begin{tabular}{|c|c|}
\hline Показники & Значення \\
\hline Час розчинення, хв. & $7 \pm 0,3$ \\
\hline Динамічна в 'язкість, $\mathrm{мПа} \cdot \mathrm{c}$ & $18 \pm 0,5$ \\
\hline Міцність студня, $\mathrm{H}$ & $9 \pm 0,5$ \\
\hline Прозорість розчину, \% & $29 \pm 1,4$ \\
\hline Температура плавлення студня, ${ }^{\circ} \mathrm{C}$ & $31 \pm 1,5$ \\
\hline Активна кислотність, $\mathrm{pH}$ & $5,5 \pm 0,3$ \\
\hline
\end{tabular}




\section{Таблиця 2}

Хімічний склад

\begin{tabular}{|l|c|}
\hline \multicolumn{1}{|c|}{ Показники } & Значення, \% \\
\hline Вологи & $14,0 \pm 0,7$ \\
\hline Білка & $81,0 \pm 4,1$ \\
\hline Жиру & $1,2 \pm 0,07$ \\
\hline Мінеральних речовин & $1,3 \pm 0,07$ \\
\hline
\end{tabular}

Запропонований спосіб виробництва желатину на основі прісноводної рибної сировини дозволить розширити асортимент вітчизняного желатину шляхом раціонального використання малоцінної рибної сировини 3 білого амура.

\section{Лiтература:}

1. Као Тхи Хуе. Обоснование и разработка технологии получения структурообразователя из кожи рыб : дис... канд. техн. наук: 05.18.04 / Као Тхи Хуе. - Москва, 2012. - С, 2012. - 143 с.

2. Пат. 2340210, Россия, МПК А23L1/0562. Способ производства натурального структурообразователя / Л.К. Петриченко, С.П. Петриченко, Заявка № 2007112439/13; заявл. 03.04.2007. 10.12.2008.

\section{Rerferences.}

1. Kao Thi Hue. The substantiation and development of the technology of obtaining a structuring agent from the skin of fish: Diss ... Cand. tech Sciences: 05.18.04 / Kao Thi Hue. - Moscow, 2012. - C, 2012. - 143 p.

2. Pat. 2340210, Russia, IPC A23L1 / 0562. The method of production of natural structuring agent / Л.К. Petrichenko, SP Petritshenko, Application No. 2007112439/13; stated. 03/04/2007 10.12.2008.

Abstract. The article deals with perspective directions of white amur processing. The known methods of production of fish gelatin are given and their disadvantages analyzed. The results of physicochemical indices and chemical composition of fish gelatin based on white amur are presented.

Key words: method of production, gelatin, freshwater fish, physical and chemical indices.

Статтю віправлено: 19.06.2019 p. (C) Іванюта А.О., Нестеренко Н.А. 


\section{Экспертно-рецензионный Совет журнала}

Expert-Peer Review Board of the journal

Абдулвелеева Рауза Рашитовна, кандидат педагогических наук, доцент, Оренбургский государственный университет, Россия

Артюхина Марина Владимировна, кандидат экономических наук, доцент, Славянский государственный педагогический университет, Украина

Афинская Зоя Николаевна, кандидат филологических наук, доцент, Московский государственный университет имени М.В. Ломоносова, Россия

Башлай Сергей Викторович, кандидат экономических наук, доцент, Украинская академия банковского дела, Украина

Белоус Татьяна Михайловна, кандидат медицинских наук, доцент, Буковинская государственная медицинская академия, Украина

Бондаренко Юлия Сергеевна, кандидат педагогических наук, доцент, ПГУ им. Т.Г. Шевчекнко кафедра психологии, Казахстан

Бутырский Александр Геннадьевич, кандидат медицинских наук, доцент, Медицинская академия имени С.И. Георгиевского ФГАОУ ВО КФУ имени В.И. Вернадского, Россия

Василишин Виталий Ярославович, кандидат технических наук, доцент, Ивано-Франковский национальный технический университет нефти и газа, Украина

Войцеховский Владимир Иванович, кандидат сельскохозяйственных наук, доцент, Национальный университет биоресурсов и природопользования Украины, Украина

Гаврилова Ирина Викторовна, кандидат педагогических наук, доцент, Магнитогорский государственный технический университет имени Г.И.Носова, Россия

Гинис Лариса Александровна, кандидат педагогических наук, доцент, Южный федеральный университет, Россия

Гутова Светлана Георгиевна, кандидат философских наук, доцент, Нижневартовский государственный университет, Россия

Зубков Руслан Сергеевич, кандидат экономических наук, ГП НПКГ "Зоря"-"Машпроект" г. Николаев, Украина

Ивлев Антон Васильевич, кандидат экономических наук, доцент, Магнитогорский государственный технический университет имени Г.И.Носова, Россия

Идрисова Земфира Назиповна, кандидат экономических наук, доцент, Уфимский государственный авиационный технический университет, Россия

Илиев Веселин, кандидат технических наук, доцент, Болгария

Кириллова Татьяна Климентьевна, кандидат экономических наук, доцент, Иркутский государственный университет путей сообщения, Россия

Коваленко Татьяна Антольевна, кандидат технических наук, Поволжский государственный университет телекоммуникаций и информатики, Россия

Котова Светлана Сергеевна, кандидат педагогических наук, доцент, Российский государственный профессиональнопедагогический университет, Россия

Кухтенко Галина Павловна, кандидат фармацевтических наук, доцент, Национальный фармацевтический университет Украины, Украина

Лобачева Ольга Леонидовна, кандидат химических наук, доцент, Горный университет, Россия

Ляменко Дмитрий Алексеевич, кандидат географических наук, доцент, Национальный транспортный университет, Украина

Макаренко Андрей Викторович, кандидат педагогических наук, доцент, Донбасский государственный педагогический университет, Украина

Мельников Александр Юрьевич, кандидат технических наук, доцент, Донбасская государственная машиностроительная академия, Украина

Мороз Людмила Ивановна, кандидат экономических наук, доцент, Национальный университет "Львовская политехника", Украина

Музылёв Дмитрий Александрович, кандидат технических наук, доцент, Харьковский национальный технический университет сельского хозяйства имени Петра Василенко, Украина

Надопта Татьяна Анатолиевна, кандидат технических наук, ст. преп, Хмельницкий национальный университет, Украина

Напалков Сергей Васильевич, кандидат педагогических наук, Нижегородский государственный университет имени Н.И. Лобачевского, Арзамасский филиал ННГУ, Россия

Никулина Евгения Викторовна, кандидат экономических наук, доцент, Белгородский государственный национальный исследовательский университет, Россия

Орлова Анна Викторовна, кандидат экономических наук, доцент, Белгородский государственный национальный исследовательский университет, Россия

Осипов Виктор Авенирович, доктор географических наук, профессор, Тюменский государственный университет, Россия

Привалов Евгений Евграфович, кандидат технических наук, доцент, Ставропольский государственный аграрный университет, Россия

Пьжьянова Наталия Владимировна, кандидат искусствоведения, доцент, Украина

Сегин Любомир Васильевич, кандидат филологических наук, доцент, Славянский государственный педагогический университет, Украина

Сергиенко Александр Алексеевич, доктор медицинских наук, профессор, Львовский национальный медицинский университет им. Даниила Галицкого, Украина

Сочинская-Сибирцева Ирина Николаевна, кандидат экономических наук, доцент, Кировоградский государственный технический университет, Украина

Сысоева Вера Александровна, кандидат архитектурных наук, доцент, Белорусский национальный технический университет, Беларусь

Тлеуов Асхат Халилович, доктор технических наук, профессор, Казахский агротехнический университет, Казахстан

Ходжаева Гюльназ Казым кызы, кандидат географических наук, Россия

Чигиринский Юлий Львович, кандидат технических наук, доцент, Волгоградский государственный технический университет, Россия

Шехмирзова Анджела Мухарбиевна, кандидат педагогических наук, доцент, Адыгейский государственный университет, Россия

Шпинковский Александр Анатольевич, кандидат технических наук, доцент, Одесский национальный политехнический университет, Украина 


\section{СОДЕРЖАНИЕ / CONTENTS}

\section{Инновационная техника, технологии и промышленность}

Innovative engineering, technology and industry

Інноваційна техніка, технологї і промисловість

https://www.scilook.eu/index.php/slif/article/view/slif14-017

ASSESSMENT OF VISUAL PERFORMANCE IN TERMS OF LED LIGHTING ОЦЕНКА ЗРИТЕЛЬНОЙ РАБОТОСПОСОБНОСТИ В УСЛОВИЯХ СВЕТОДИОДНОГО ОСВЕЩЕНИЯ

Galtsova E.M. / Гальциова Е. М.

https://www.scilook.eu/index.php/slif/article/view/slif14-018

DETERMINATION OF RADIAL AND CIRCUMFERENTIAL STRESSES BY

SOLVING THE LAME-GADOLIN TASK

ОПРЕДЕЛЕНИЕ РАДИАЛЬНЫХ И ОКРУЖНЫХ НАПРЯЖЕНИЙ НА ОСНОВЕ

РЕШЕНИЯ ЗАДАЧИ ЛАМЕ-ГАДОЛИНА

Savinov A.S. / Савинов A.C., Angold K.V. / Ангольд K.B.

https://www.scilook.eu/index.php/slif/article/view/slif14-027

METHOD OF PRODUCTION GELATINE BASED ON FRESHWATER FISH

СПОСІБ ВИРОБНИЦТВА ЖЕЛАТИНУ НА ОСНОВІ ПРІСНОВОДНОЇ РИБНОЇ

СИРОВИНИ

Ivanyta A.O./ Іванюта A.O., Nesterenko N.A/ Нестеренко H. A.

Информатика, кибернетика и автоматика

Computer science, cybernetics and automatics

Інформатика, кібернетика та автоматика

https://www.scilook.eu/index.php/slif/article/view/slif14-010

23

SLECTION OF STRUCTURE AND HYPER-PARAMETERS OF SVM FOR

EFICIENT SOLUTION OF THE TASKS OF CLASSIFICATION OF

EECTROMYOGRAPHY SIGNALS

ВЫБОР СТРУКТУРЫ И ГИПЕРПАРАМЕТРОВ ЛVМ ДЛЯ ЭФФЕКТИВНОГО РЕШЕНИЯ

ЗАДАЧ КЛАССИФИКАЦИИ СИГНАЛОВ ЭЛЕКТРОМИОГРАФИИ

Semendarov A.V. / Семендаров A.B.

https://www.scilook.eu/index.php/slif/article/view/slif14-016

INFORMATIVE INDICATORS FOR BICYCLE ERGOMETRY

ИНФОРМАТИВНЫЕ ПОКАЗАТЕЛИ ВЕЛОЭРГОМЕТРИИ

Kovalenko M.M. / Коваленко H.H., Lysiuk D.S. / Льсюк Д.С., Kutsiak O.A. / Куияяк А.А.

https://www.scilook.eu/index.php/slif/article/view/slif14-021

VERIFICATION SYSTEM OF TASK SOLUTIONS WITH TELEGRAM API

СИСТЕМА ВЕРИФІКАЦІЇ РОЗВ 'ЯЗКІВ ЗАДАЧ З ВИКОРИСТАННЯМ ТЕLЕGRАМ АРI

Dasyuk A.M. / Дасюк A. M., Veres M. M. / Верес M. М. 
A METHOD OF CONSTRUCTING MULTIBAND LOGIC ELEMENT

EVEN/ODD ON COMPLEMENTARY MOS TRANSISTORS

МЕТОД ПОСТРОЕНИЯ МНОГОВХОДОВОГО ЛОГИЧЕСКОГО ЭЛЕМЕНТА

ЧЁТНОСТЬ/НЕЧЁТНОСТЬ НА КОМПЛЕМЕНТАРНЫХ МОП-ТРАНЗИСТОРАХ

Paulin O.N./Паулин O.H.

https://www.scilook.eu/index.php/slif/article/view/slif14-029

AUTOMATIZATION PROCESSORS GETTING RESULTS FROM PORTABLE

MEDICAL AND AUXILIARY DEVICES (IoT) WITH USE OF IBM WATSON АВТОМАТИЗАЦІЯ ПРОЦЕСІВ ОТРИМАННЯ РІШЕНЬ 3 ОБРОБКОЮ ДАНИХ 3 ПОРТАТИВНИХ МЕДИЧНИХ ТА ДОПОМІЖНИХ ЗАСОБІВ (IоТ) 3 ВИКОРИСТАННЯМ CИСТЕМ IBM WATSON

Haupt O.F. / Гaynm O.Ф., Riabko R.S. / Рябко P.C.

Развитие транспорта и транспортных систем Development of transport and transportation systems

Розвиток транспорту і транспортних систем https://www.scilook.eu/index.php/slif/article/view/slif14-009

INFLUENCE OF INTERNATIONAL MARITIME CONVENTIONS ON

PROTECTION OF THE MARINE ENVIRONMENT

ВЛИЯНИЕ МЕЖДУНАРОДНЫХ МОРСКИХ КОНВЕНЦИЙ НА ПРОЦЕССЫ ЗАЩИТЫ МОРСКОЙ СРЕДЫ

Zayats S.V. / Заяи C. B., Voloshin A.A. / Волошин A.A.

https://www.scilook.eu/index.php/slif/article/view/slif14-034

THE MAIN MALFUNCTIONS AND FEATURES OF THE PREPARATION OF HEAVY MACHINERY ON THE EXAMPLE OF THE DUMP TRUCK BELAZ 75131 IN THE FAR NORTH

ОСНОВНЫЕ НЕИСПРАВНОСТИ И ОСОБЕННОСТИ ПОДГОТОВКИ ТЯЖЕЛОЙ ТЕХНИКИ НА ПРИМЕРЕ КАРЬЕРНОГО САМОСВАЛА БЕЛАЗ 75131 В УСЛОВИЯХ КРАЙНЕГО СЕВЕРА

Toskunin I.S. / Тоскунин И.С.

https://www.scilook.eu/index.php/slif/article/view/slif14-005

Архитектура и строительство Architecture and construction Архітектура і будівництво

FEATURES OF CALCULATION OF STEEL-CONCRETE CONSTRUCTIONS ОСОБЕННОСТИ РАСЧЕТА СТАЛЕЖЕЛЕЗОБЕТОННЫХ КОНСТРУКЦИЙ Panova A.S. / Панова A.C., Sergeev E.I. / Сергеев Е.И. 
ANALYSIS OF THE ESTIMATES DISTRIBUTION OF THE REGRESSION

MODEL PARAMETERS FOR THE FIELD EMISSION SIGNAL

АНАЛИЗ РАСПРЕДЕЛЕНИЯ ОЦЕНОК ПАРАМЕТРОВ РЕГРЕССИОННОЙ МОДЕЛИ СИГНАЛА ПОЛЕВОЙ ЭМИССИИ

Li A.D. / Ли А.Д., Pakhomova A.A. / Пахомова A.A.

\section{Медицина и здравоохранение \\ Medicine and healthcare \\ Медиичина і охорона здоров'я}

https://www.scilook.eu/index.php/slif/article/view/slif14-012

ASSESSMENT OF THE RISK OF CARDIOVASCULAR DISEASES

ОЦІНКА РИЗИКУ ВИНИКНЕННЯ СЕРЦЕВО-СУДИННИХ ЗАХВОРЮВАНЬ

Yakovenko V.G. / Яковенко В.Г., PanchenkoV.V. / Панченко В.В.

https://www.scilook.eu/index.php/slif/article/view/slif14-023

Биология и экология Biology and ecology Біологія та екологія

THE EXPERIENCE OF DETERMINING THE INFLUENCE OF RADIATION OF

INCANDESCENT LAMPS AND LED LAMPS ON BARLEY SEEDLINGS ДОСВІД ВИЯВЛЕННЯ ВПЛИВУ ВИПРОМІНЮВАННЯ ВІД ЛАМП РОЗЖАРЮВАННЯ І СВІТЛОДІОДНИХ ЛАМП НА ПРОРОСТКИ ЯЧМЕНЮ

Kundelchuk O.P./Кундельчук O.П., Kotovskii I.N. / Котовський I.M.

Goncharenko T.L./Гончаренко T.Л., Golovko N.Yи. / Головко Н.Ю.

Сельское, лесное, рыбное и водное хозяйство Agriculture, forestry, fishery and water management

Сільське, лісове, рибне та водне господарство

https://www.scilook.eu/index.php/slif/article/view/slif14-004

STATE AND PROSPECTS OF DEVELOPMENT OF POULTRY FARMING IN KRASNODAR TERRITORY

СОСТОЯНИЕ И ПЕРСПЕКТИВЫ РАЗВИТИЯ ПТИЦЕВОДСТВА В КРАСНОДАРСКОМ KPAE

Shevchenko A.N. / Шевченко A.H.

https://www.scilook.eu/index.php/slif/article/view/slif14-033

LAND COVER CHANGE IN RIVER DELTAS OF THE BLACK SEA

SOUTHERN COAST

ИЗМЕНЕНИЕ ЗЕМЕЛЬНОГО ПОКРОВА В ДЕЛЬТАХ РЕК ЮЖНОГО ПОБЕРЕЖЬЯ

ЧЕРНОГО МОРЯ

Starodubtsev V.M. / Стародубиев B.M. 
Международный периодический рещензируемый научный журнал

\section{НАУЧНЫЙ ВЗГЛЯД В БУДУЩЕЕ \\ Выпуск 14 \\ Tом 1}

На украинском, русском и английском языках

Входит в международные наукометрические базы (высокий импактфактор):

РИНЦ, INDEXCOPERNICUS (ICI 88.47)

Научные достижения Авторов были также представлены для открытого обсуждения на международной научной конференции «Интеллектуальный потенцииал ХХІ века '2019» (с 19 по 20 июня 2019 г.)

Решением международной научной конференции работы, которые получили положительную оценку, были рекомендованы к изданию в журнале.

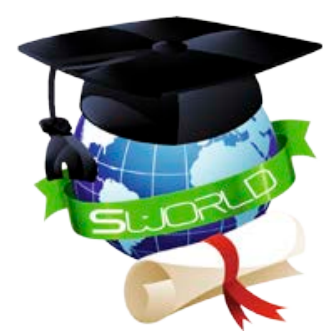

www.sworld.education

Разработка оригинал-макета - КУПРИЕНКО СВ

Подписано в печать: 14.07.2019

Формат 60х84/16. Печать цифровая. Усл.печ.л. 7,09

Тираж 500. Заказ №ua14-1.

Издано:

ИНСТИТУТ МОРЕХОЗЯЙСТВА И ПРЕДПРИНИМАТЕЛЬСТВА

совместно С

КУПРИЕНКО СЕРГЕЙ ВАСИЛЬЕВИЧ

$\mathrm{A} /$ Я 38, Одесса, 65001

e-mail: orgcom@sworld.education

Свидетельство субъекта издательского дела ДК-4298

Издатель не несет ответственности за

достоверность информации и научные результать, представленные в статьях

ФЛП Москвин А.А. Цифровая типография “Сору-Art”

г. Запорожье
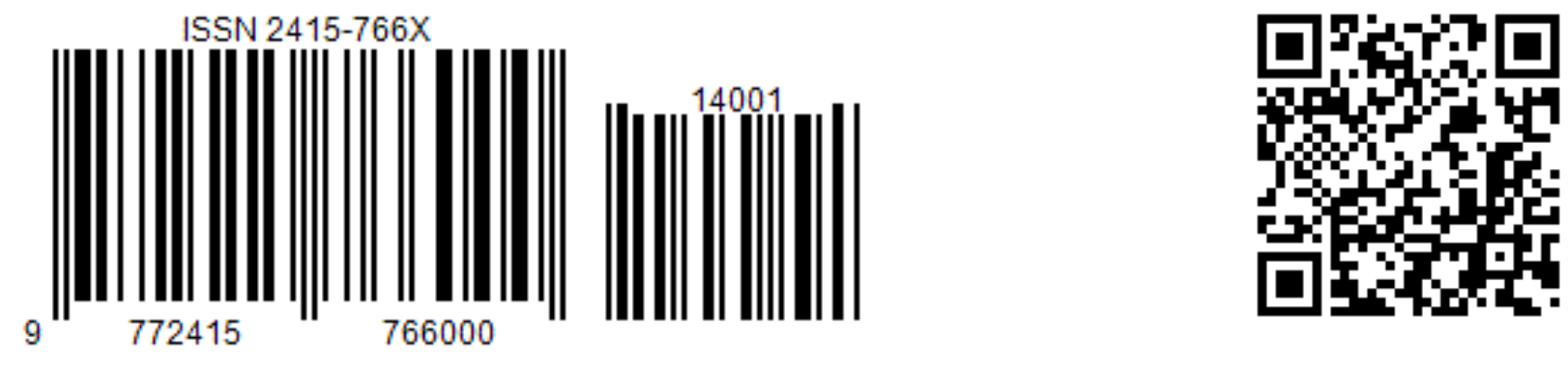


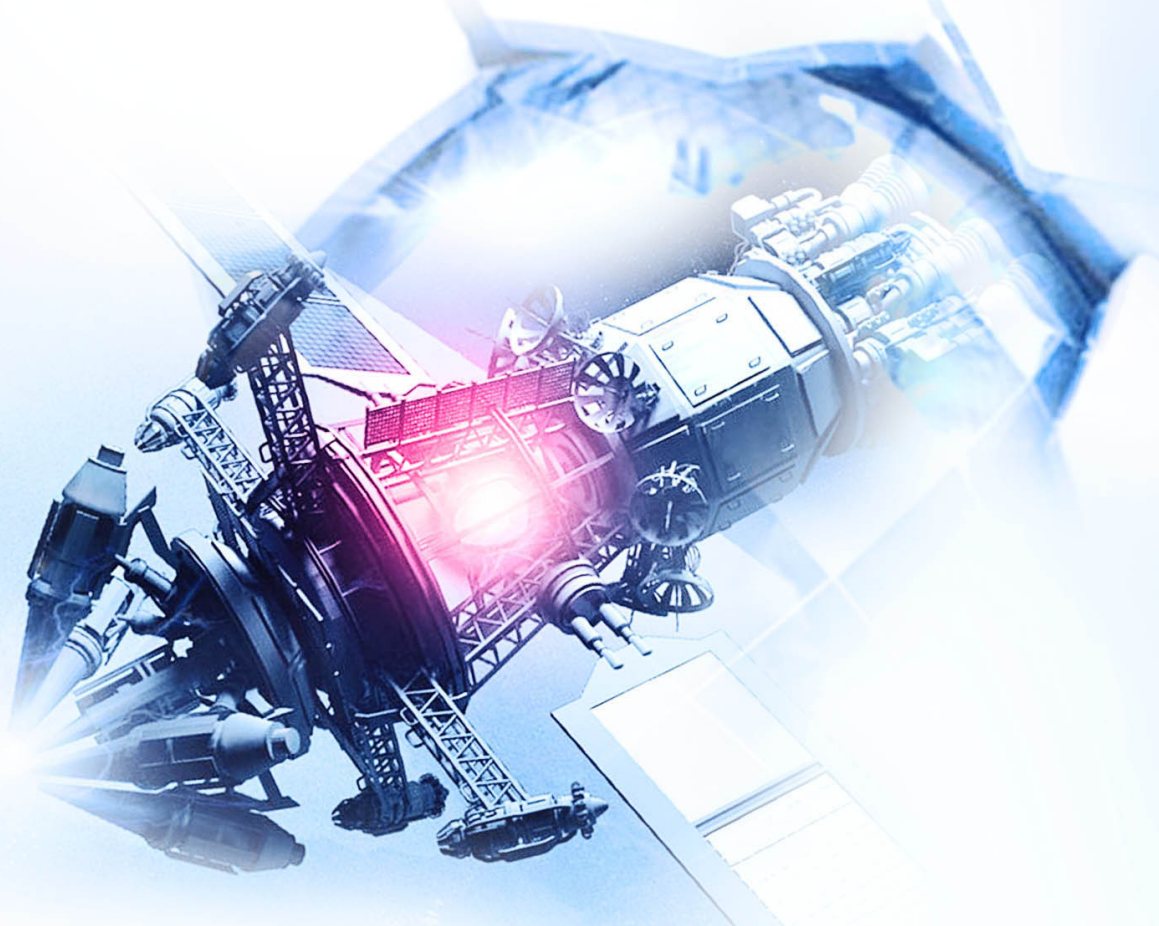

www.scilook.eu

www.sworld.com.ua

тел: +380 (66) 790-12-05

$+7(499)$ 350-80-55

e-mail: orgcom@sworld.com.ua

ksv80@rambler.ru 